\title{
PROCESSOS DE ALTERIZAÇÃO E CONSIDERAÇÃO MORAL: $O$ QUE O ENSINO DE BIOLOGIA CELULAR TEM A VER COM ISSO? ${ }^{* 1}$
}

\author{
Ayane de Souza Paiva \\ Rosiléia Oliveira de Almeida \\ Ana Paula Miranda Guimarães
}

\section{Introdução}

São inegáveis os avanços no ensino de biologia quanto aos seus compromissos ontológicos e formativos numa perspectiva de transformação positiva da sociedade, com esforços de professoras/es e pesquisadoras/es em praticar e investigar o ensino de caráter crítico e cordial $^{2}$. No entanto, ainda nos deparamos com estruturas e práticas curriculares fundamentadas em abordagens fragmentadoras e acríticas, que têm, em linhas gerais, caráter cientificista e conceitualista. O cientificismo consiste na crença exagerada no poder da ciência, por meio de uma ideia hegemônica de que ela é permeada por valores, discursos e práticas apenas benéficos, de modo que o conhecimento científico é visto como único e verdadeiro (COBERN; LOVING, 2001). Já o conceitualismo envolve o "predomínio de exposição, pelo professor, e memorização, pelos estudantes, de fato, termos e definições científicos, os quais são assumidos como o verdadeiro

*DOI - 10.29388/978-65-86678-66-6-f.139-156

${ }^{1}$ Este capítulo traz um recorte da tese de doutorado defendida pela primeira autora, no Programa de Pós-Graduação em Ensino, Filosofia e História das Ciências (UFBA/UEFS), intitulada Princípios de design para o ensino de biologia celular: pensamento crítico e ação sociopolítica inspirados no caso de Henrietta Lacks. Disponível em: https://repositorio.ufba.br/ri/bitstream/ri/29744/1/Tese\%20Ayane

\%20Paiva_PPGEFHC_2019.pdf.

${ }^{2}$ Para ter acesso a trabalhos nessa perspectiva, que privilegiam a formação a partir de valores sociais pertinentes aos Direitos Humanos, sugerimos a leitura do livro "Conteúdos cordiais: biologia humanizada para uma escola sem mordaça", organizado pela professora Glória Queiroz e pelos professores Pedro Teixeira e Roberto Dalmo, no qual publicamos o capítulo intitulado "A história de Henrietta Lacks como inspiração para o ensino de Biologia Celular voltado para a formação crítica sobre raça e gênero". 
objeto da educação, em detrimento de aprendizagem de valores, normas e atitudes" (CONRADO; NUNES-NETO, 2018, p. 78-79).

Estudos recentes indicam que o ensino de Biologia Celular tem sido realizado de modo cientificista e conceitualista, com restrito espaço para discussão histórica, epistemológica e axiológica (PAIVA; GUIMARÃES; ALMEIDA, 2018). Carvalho, Nunes-Neto e El-Hani (2011) estimaram que, durante o Ensino Médio, somente na área de biologia celular, são ensinados mais de 300 conceitos novos, muitos deles nomeados com dois ou três termos sinônimos, com excessivo foco sobre memorização. Ademais, a ausência de debates sobre a construção do conhecimento sobre célula, a falta de aplicabilidade deste em situações cotidianas e o raro foco em debates sobre questões sociocientíficas (LIMA; TEIXEIRA, 2011) vêm sendo descritos na literatura sobre educação científica.

Em oposição a essas práticas de ensino de biologia celular, partimos dos pressupostos filosóficos da pedagogia crítica de Paulo Freire, a qual entende que é necessária uma abordagem que faça da opressão e de suas causas objeto da reflexão das pessoas oprimidas, de que resultará em engajamento necessário na luta pela libertação (FREIRE, 2017). A Pedagogia freireana é entendida por nós, assim como elaborado por Gadotti (2001 apud TORRES, 2008), como sendo eminentemente transdisciplinar, ao entender a escola como um espaço que possibilita a ampliação de visões sobre a complexidade que envolve a vida na e com a sociedade. Freire propõe uma educação como sonho utópico possível desde a década de 1960, período de grandes "lutas pela libertação: lutas anticoloniais, anticlassistas, lutas por igualdade de gênero, por igualdade étnica e racial. Mas também uma década onde se revalorizou a intimidade, o abraço, o ato de amor" (TORRES, 2008, p. 53).

A formação humanista e crítica freireana se articula com a educação sobre as relações entre Ciência-Tecnologia-Sociedade-Ambiente (CTSA), já que esse movimento educacional, surgido nas décadas de 1960 e 1970, é reconhecido por boa parte das/os pesquisadoras/es como uma proposição para mudança do status quo, entendendo a ciência nos contextos sociais, tecnológicos, culturais, éticos e políticos (PEDRETTI; NAZIR, 2011) como via de superação do ensino fragmentado e tecnicista (PÉREZ; LOZANO, 2013). Na perspectiva freireana, a superação da contradição opressores-oprimidos ocorre a partir da historicidade, como elemento de compreensão da realidade para a mudança, por meio da análise sobre as variadas questões sociais, científicas, tecnológicas, ambientais, via dialogicidade, visando a liberta- 
ção da alienação pelos caminhos da humanização, sendo empreendida por uma educação explicitamente politizada (FREIRE, 2017).

$\mathrm{Na}$ fase de expansão do enfoque CTSA, no início do século XXI, ocorreu o surgimento das Questões Sociocientíficas (QSC) (PÉREZ; LOZANO, 2013). QSC, enquanto ferramenta didática, são situações ou problemas controversos e complexos que requerem uma abordagem contextualizada e interdisciplinar, sendo os conhecimentos científicos essenciais para a compreensão e a busca de soluções para essas questões, embora sejam também relevantes conhecimentos em história e filosofia, especialmente em ética (CONRADO; NUNES-NETO, 2018). A intenção do ensino via QSC, manifestada e assumidamente político, é promover o olhar crítico para o tipo de ciência e tecnologia predominante e para os valores sociais, políticos, econômicos e ético-morais que orientam seu desenvolvimento, bem como questionar o que pode e deve ser alterado para alcançarmos democracias socialmente mais justas (HODSON, 2018).

Com base nesses pressupostos, a pesquisa focalizou o ensino de Biologia Celular associado a debates éticos sobre progresso da ciência e processos de alterização ligados ao racismo, sexismo e opressão de classe, no contexto do Ensino Médio.

A alterização corresponde ao processo cultural de produção de alteridades por meio da delimitação, rotulação e categorização das formas possíveis de ser outro, a partir de determinados marcos sócio-históricos (ARTEAGA et al., 2015), sendo esse processo comumente envolvido na construção das identidades. No entanto, a alterização se torna negativa quando gera marginalização, subjugação e exclusão, a partir de algum tipo de reforço a noções de normalidade, caracterizando as diferenças como desvios, a partir de categorizações de inferioridade (ARTEAGA et al., 2015), sendo exemplos o racismo, o sexismo, a opressão de classe, a heteronormatividade e o especismo ${ }^{3}$. Esses processos de alterização são referidos, no campo da ética, pela ideia de exclusão da consideração moral, ou de exclusão do círculo de consideração moral (SINGER, 2004). A consideração moral diz respeito à possibilidade de incluir um ser (ou grupos de seres) num estatuto moral que permita que ele(s) não seja(m) ignorado(s) ou tratado(s) de modo arbitrário. $\mathrm{O}$ critério para a consideração moral de animais não hu-

\footnotetext{
${ }^{3}$ Tipo de preconceito ou atitude que favorece os interesses dos membros de uma espécie em detrimento dos interesses dos membros de outras espécies (SINGER, 2004). O termo foi cunhado por Richard Ryder e tem sido adotado desde a primeira edição do livro "Libertação Animal" de Peter Singer.
} 
manos que adotamos é o princípio da igual consideração de interesses semelhantes (SINGER, 2012), que preconiza que se atribua o mesmo peso, nas nossas deliberações morais, aos interesses semelhantes de todos os afetados pelas nossas ações, pela compreensão de que um interesse é um interesse, independentemente de quem apresenta esse interesse.

Os debates éticos empreendidos na pesquisa contemplam três processos de alterização conducentes à exclusão da consideração moral sexismo, racismo e opressão de classe, aos quais Henrietta Lacks foi submetida (PAIVA et al., 2016). A história de Henrietta Lacks é promissora para trabalhar questões sociais amplas ligadas à biologia celular, mais especificamente mitose e câncer, pois se trata de um caso real de uma mulher, pobre e negra, nascida nos Estados Unidos, que teve suas células do colo de útero extraídas sem conhecimento e anuência para pesquisas sobre câncer, no contexto de leis segregacionistas, na primeira metade do século XX. Suas células - imortais, se mantidas em condições ideais de laboratório - têm, desde então, contribuído para muitos benefícios sociais (SKLOOT, 2011; PAIVA et al., 2016).

Este estudo constitui um recorte de uma pesquisa empírica que teve por finalidade investigar princípios de design de uma Sequência Didática (SD) sobre mitose e câncer, inspirada na história de Henrietta Lacks, no contexto do Ensino Médio. Neste capítulo, apresentamos a investigação sobre a expectativa de ensino que propôs orientar a análise pelas/os estudantes de situações concretas que envolvem processos de alterização conducentes à exclusão da consideração moral.

\section{Percurso metodológico}

A investigação adotou como arcabouço teórico-metodológico a Pesquisa de Design Educacional, a qual visa o estudo sistemático dos processos de planejamento, implementação, avaliação e manutenção de intervenções de ensino inovadoras, situadas em sala de aula real, objetivando a busca de solução para problemas complexos da prática educacional, por meio da elaboração de princípios de design que possam ser aplicáveis, mediante adaptações, a vários contextos (PLOMP, 2009). Esses princípios de design são declarações enunciativas que configuram apostas teóricas e educacionais e correspondem aos produtos teóricos da pesquisa (VAN DEN AKKER, 1999). O princípio de design foi assim enunciado (PAIVA, 2019, p. 130): 
Uso didático de uma QSC baseada num caso real que orienta toda a intervenção didática, para a abordagem e discussão crítica dos conteúdos de modo amplo, os quais incluem os conceitos éticos pertinentes e análise de situações concretas que envolvem processos de alterização conducentes à exclusão da consideração moral, focalizando os que conduzem a racismo, sexismo e opressão de classe na história de ciência; visando promover pensamento crítico sobre aspectos epistemológicos, históricos, axiológicos da biologia, e as implicações da mesma na sociedade. [As/Os] estudantes analisarão, em grupos, uma QSC durante toda a SD, envolvendo conceitos de biologia celular, dilemas éticos, processos negativos de alterização, progresso axiológico da ciência, questões tecnológicas e ambientais, a partir do caso.

A principal razão desse princípio é a perspectiva de que o ensino via QSC é uma importante ferramenta para capacitar as/os estudantes a considerar como as questões de base científica e as decisões que lhes dizem respeito refletem, em parte, os princípios morais e qualidades de virtude que englobam suas próprias vidas, bem como o mundo social em torno delas/es (ZEIDLER et al., 2005). Na investigação utilizamos a abordagem qualitativa de enfoque crítico-participativo com visão histórico-estrutural, a partir de uma dialética da realidade social que parte da necessidade de conhecê-la para transformá-la (TRIVIÑOS, 2012).

A pesquisa foi conduzida no contexto real da sala de aula do Instituto Federal da Bahia (IFBA), Campus Camaçari, sendo a SD aplicada nas duas turmas de terceiro ano do Ensino Médio integrado ao técnico, série em que se estuda biologia celular. A produção de dados ocorreu por meio de observação participante (GIL, 2009) da aplicação da SD em sala de aula, que garantiu contato direto da pesquisadora com o fenômeno estudado, o ensino de biologia celular. Utilizamos como formas de registro: gravação em áudio e vídeo, fotografias e caderno de campo. Como recorte para este trabalho, selecionamos os registros de uma das turmas em que a SD foi aplicada ${ }^{4}$. A partir dos registros audiovisuais e do caderno de campo foram elaborados mapas de atividades, os quais contribuíram para a contextualização dos enunciados produzidos durante a SD e orientaram a escolha de episódios

\footnotetext{
${ }^{4}$ No contexto da tese, utilizamos também a técnica de grupo focal, por meio da qual foi possível escutar as/os estudantes sobre a experiência de ensino e aprendizagem que tiveram, indicando elementos importantes para análise do princípio de design (ver PAIVA, 2019).
} 
de ensino relevantes para a análise da dinâmica discursiva estabelecida (AMARAL; MORTIMER, 2006). Um episódio pode ser definido como um conjunto de enunciados que cria o contexto para a emergência de um determinado significado ou de alguns significados relacionados, sendo apresentado na forma de sucessivos turnos de fala (AMARAL; MORTIMER, 2006).

Os sujeitos enunciadores dos discursos foram: a professora, as/os estudantes, a professora em interação com as/os estudantes e as/os estudantes em interação com outras/os estudantes. Utilizamos, como procedimentos analíticos: 1) elaboração de mapas de atividades, e 2) identificação, seleção, transcrição e análise de episódios representativos. Para a análise das informações obtidas utilizamos a Análise Crítica do Discurso (MELO, 2009; CONRADO; CONRADO, 2016).

A Análise Crítica do Discurso ( $A C D$ ) compreende o discurso como constituído por práticas sociais, as quais podem revelar processos de manutenção e abuso de poder; considera a importância da linguagem na produção, na manutenção e na mudança das relações sociais de poder; e visa aumentar a consciência de que a linguagem contribui para processos de dominação, tendo em vista que tal consciência seria o primeiro passo para a emancipação (MELO, 2009). Assim, o objeto de estudo da ACD não corresponde tão somente à língua, mas o que há por meio dela: relações de poder, institucionalização de identidades sociais, processos de inconsciência ideológica (MELO, 2009).

\section{Resultados e discussão}

Para analisar a expectativa de ensino - Orientar a análise pelas/os estudantes de situações concretas que envolvem processos de alterização conducentes à exclusão da consideração moral -, relacionada ao princípio de design que aposta no uso didático do caso de Henrietta Lacks, numa QSC, selecionamos quatro episódios de ensino.

Diante da expectativa de ensino, analisamos o episódio de ensino 1 , selecionado de interações discursivas ocorridas na primeira aula, dedicada ao caso da QSC, em que houve discussão sobre processos de alterização negativa. Os temas centrais abordados foram: segregação racial e social, relações entre o contexto social da vida das pacientes e o uso não consentido de seus tecidos na época do caso. Após leitura colaborativa e explicação do caso da QSC, que envolvia a história de Henrietta Lacks, o 
episódio foi iniciado com a exposição pela professora de questões nos slides, suscitando discussões.

Quadro 1. Episódio de ensino 1: "De um lado negros, de outro brancos".

1. Professora: E essas a gente vai dar uma conversada agora/ que é/ ((professora lê slide)) o hospital que atendeu Henrietta era único num raio de muitos quilômetros que tratava pacientes negros/ainda que os separasse em enfermarias para gente de cor/ o que você pensa a respeito dessa separação? e/ sobre a fala/ o Hospital Hopkins com sua grande população negra indigente/ não tinha escassez de material clínico/ quais as possíveis relações entre o contexto social da vida das pacientes e o uso não consentido de seus tecidos na época do caso? então/ o que que vocês acham do caso? da situação que aconteceu com ela e dessas perguntas também trazendo um pouco até pro nosso hoje em dia/ enfim/

2. Estudante A: Então/ esses casos assim de racismo/ eles são comuns até mesmo hoje em dia/ como por exemplo/ é/ nesse hospital/ as pessoas/ elas eram separadas por questão de cor/ então de um lado negros/ de outro brancos/ ((inaudível)) os brancos tem aquela coisa de que/ ah eu não vou me rebaixar ao ponto de ficar num mesmo local que um negro/ mas é bem comum que a gente vê várias notícias por aí de casos que acontecem em aviões/ que sempre tem aquela pessoa daquela classe e tem uma outra pessoa negra que senta do lado/ ou até mesmo no mesmo setor e aí começa aquela discriminação não só pelos passageiros/ como pelos próprios funcionários da companhia aérea/

3. Professora: Exatamente//

4. Estudante A: E/

5. Professora: $E$ acontece ainda/ então/ né/

6. Estudante B: Sobre a segunda questão/ no caso/ é/ fala que/ usava/ não tinha consentimento das pessoas pra usar seus tecidos na/ em experimentos etc./

7. Professora: Sim/

8. Estudante B: Era como se não considerasse essas pessoas como pessoas/ como se elas fossem animais praticamente/ que cê podia recolher lá o material/ não tava entendendo nada que tava acontecendo e não precisava explicar nada pra ela//

9. Professora: Nem sabia/ né/ que pegou/ Ela/ por exemplo/ nem sabia/

10. Estudante B: Justamente/ É como se fossem realmente animais/ que tivesse recolhendo material/ em um animal/ por exemplo/ não entende do que se trata e você não vai chegar e ficar explicando pro animal o que aconteceu/ tava tratando essa pessoa dessa mesma forma/

11. Professora: Exatamente/

12. Estudante $\mathrm{C}$ : Eu acho que essa questão de você retirar o material da pessoa sem avisar/ acho que nem é tanto por ela não entender/ porque você pode 
explicar pra ela/ eu posso tirar isso de você/ pra fazer pesquisa/ pra ajudar a ciência/ eu acho que não teria problema/ eu acho que não é/ o medo dos pesquisadores de isso se dar com algo bom/ que foi o que aconteceu com o caso das células dela/ e acabar exigindo/ é/ dinheiro/ algo que a família queira/ ajuda/ e eles não querem ter esse vínculo com a família/ em especial/

13. Estudante $\mathrm{D}$ : $\mathrm{E}$ a divulgação também do nome/ né

14. Professora: Isso/

15. Estudante D: por exemplo, se fosse haver uma divulgação e essa descoberta/ e fosse colocar no nome de uma mulher/ negra//

16. Professora: É. Negra e pobre/ né?

17. Estudante D: Absurdo isso/ não pode/ então/ já apaga o nome dela e finge que nada aconteceu// ((ironia))

18. Professora: Exato/ alguém quer falar mais alguma coisa/ gente? Pode falar/ ((entonação de prosseguimento))

19. Estudante E: Tipo/ esse caso aconteceu nos Estados Unidos e lá eles têm/ é/ o racismo obviamente diferente daqui/((inaudível)) por exemplo/ lá eles são mais separatistas/ só negros de um lado e brancos de outro/ não/ aqui aconteceu a miscigenação/ então os casos ocorrem de maneiras um pouco mais conflituosas/ e mesmo assim a gente consegue correlacionar a outras coisas que acontecem/ mas existe bem essa questão de não querer que a imagem do negro seja vinculada a um hospital ((inaudível)) hospital que seja mais influenciador ((inaudível)).

20. Professora: Exatamente/

Esse episódio de ensino ilustra como a abordagem do caso da QSC e o uso das questões orientadoras da discussão foram potenciais para que as/os estudantes analisassem situações concretas que envolvem processos de alterização negativa. Os turnos de fala 2 e 19 evidenciam essa constatação, já que, após as questões postas pela professora, os estudantes A e E realizam associação da segregação racial a que Henrietta e demais pacientes estiveram submetidas/os na época do caso com situações atuais de racismo. Nos turnos de fala 2 e 19 também é reconhecida problemática do racismo. No turno de fala 8, a estudante B menciona: "Era como se não considerasse essas pessoas como pessoas/ como se elas fossem animais praticamente/ que cê podia recolher lá o material/ não tava entendendo nada que tava acontecendo e não precisava explicar nada pra ela//". Este turno traz dois elementos importantes sobre análise de processos de alterização negativa relacionados ao caso, a saber:

1) A análise do processo alterizador no que se refere à animalização da pessoa negra, aspecto que poderia ter sido melhor explorado no 
processo de ensino, já que discutir questões éticas e políticas da desumanização da pessoa negra pode ser potencial para o reconhecimento de elementos opressivos que foram historicamente naturalizados por diferentes sistemas de dominação, que atuavam/atuam nos campos mentais, psicológicos e subjetivos da pessoa negra. O processo de desumanização da pessoa negra liga-se à exploração colonial, que é uma história de opressão per si, em que a Europa multiplicou as divisões, as oposições, forjou classes e racismos e buscou por todos os meios implementar a estratificação das sociedades colonizadas (FANON, 1968). Neste processo, o objetivo era rebaixar as pessoas colonizadas ao nível do macaco superior para justificar que o colono as tratasse como bestas de carga, de modo que a violência colonial não visava apenas garantir a submissão das pessoas, mas fomentar a desumanização. Para desumanizá-las e animalizá-las tudo era retirado, desde sua cultura (como seu idioma e modos de ser), sua força física (pelo excesso de trabalho imposto e desnutrição) até sua autonomia para tomar decisões, estando essas pessoas na zona do não-ser, por meio da violência simbólica ou física (FANON, 1968).

Um outro elemento relevante que poderia ter sido explorado seria a forma como a medicina fez parte do sistema de opressões, uma vez que, como pontuou Fanon (1968), esta era uma ciência despolitizada, a serviço de determinados grupos sociais e às vezes inexistente nas colônias. No contexto do caso em estudo, a primeira metade do século XX, em que a segregação racial tinha aparato legal nos Estados Unidos, há um marco de variadas formas de desumanização da pessoa negra, tais como: histerectomias injustificáveis (SKLOOT, 2011) e esterilização cirúrgica (DAVIS, 2016), em mulheres negras e pobres; estudo experimental, realizado em Tuskegee, em que pessoas negras doentes de sífilis morreram pelo não oferecimento de antibióticos (GAMBLE, 1997); pessoas negras sequestradas por hospitais para pesquisa (SKLOOT, 2011).

2) Por outro lado, de um ótica não-antropocêntrica, podemos considerar também nesse episódio a negação da consideração moral aos animais não-humanos, quando a estudante menciona "como se elas fossem animais praticamente", o que pode implicar numa ideia de que os corpos de animais não-humanos podem ser utilizados para pesquisas sem qualquer critério moral, o que segue nos turnos de fala 9, 10 e 11, perspectiva que a professora não problematizou. Embora possam existir pesquisas com animais não-humanos que não incorram em sofrimento, e talvez tenha sido essa a perspectiva da estudante, avaliamos que, ao tratar de alterizações 
negativas, o processo de ensino perdeu a oportunidade de promover uma discussão sobre o uso de animais não-humanos pela ciência, que permitisse problematizar valores, discursos e práticas especistas. Embora em outros momentos da SD, como na aula 3, tenha sido abordado explicitamente o problema moral do especismo enquanto um tipo de discriminação arbitrária daqueles que não pertencem a uma determinada espécie, do qual decorrem diferentes tipos de subjugação e sofrimento (SINGER, 2004; ADAMS, 2012), este seria um momento adequado para iniciar uma reflexão sobre essa forma de alterização.

Podemos concluir que o discurso presente no turno de fala 8 e, por extensão, em todo o episódio, apresenta tanto características de resistência, ao denunciar valores, discursos e práticas questionáveis no aspecto ético - no que se refere à animalização da pessoa negra - quanto sustenta es tratégias discursivas hegemônicas - ao não desconstruir a lógica especista do tratamento de animais não-humanos pela ciência.

A discussão ocorrida entre os turnos 12 e 16 mostra a importante relação entre aspectos de alterização negativa ligados a classe social, gênero e raça, e a ligação de tais alterizações com a produção do conhecimento científico. Para Freire (apud SANTOS, 2008), além de mostrar para as/os estudantes que a ciência está presente na vida diária, é preciso elucidar a contradição dessa presença na sociedade.

Ainda na aula 1 , na continuação do debate sobre os aspectos alterizadores presentes no caso de Henrietta Lacks, selecionamos o episódio abaixo.

Quadro 2. Episódio de ensino 2: "Tanto pra negro quanto pra branco essa lei?".

1. Professora: E a questão própria da utilização do corpo/ né/ assim/ é/ poxa/ mesmo que fosse pro bem da ciência/ vocês acham que essa/ esse uso realmente/ podia ser utilizado o corpo dela? Não importa pro que fosse né/ eu acho que a pessoa/ enfim/ a pessoa/ ela/ é importante ela/ ela pelo menos saber/ né/ Só que infelizmente/ nesse época/ esse caso aconteceu em $1920^{1}$ / a lei/ ela/ não precisava ter o consentimento/ na época/ era livre isso/ isso que é o grande problema que a gente até vai ver um pouquinho mais à frente/ então/ infelizmente/

\footnotetext{
${ }^{1}$ No turno de fala 1, a professora menciona o ano de 1920 como sendo o período em que aconteceu o caso de Henrietta, porém o caso ocorreu em 1950, embora tenham ocorrido outros casos de uso de células do colo do útero de mulheres sem conhecimento e consentimento desde aquela data, naquele contexto. Contudo, o objetivo de debate sobre alterizações negativas não foi comprometido por conta do equívoco.
} 
eles não tavam infringindo nenhuma lei/ tavam infringindo eticamente/ né/ mas não lei/ eticamente/ moralmente/ né/ realmente estavam/ e a outra coisa que eu acho importante a gente comentar/ do negócio da/ que o hospital a quilômetros/ né/ que fala/ o único num raio de muitos quilômetros/ ou seja/ existiam outros hospitais/ apenas um ((professora é enfática e gesticula o número um com o dedo)) é que aceitava negros e quando aceitavam era segregado/ Então isso é algo muito complicado de/ porque assim mesmo que/ de se pensar/ da gente ficar refletindo mesmo assim/ Alguém tem mais alguma coisa/ falar mais alguma coisa? ((entonação de prosseguimento))

2. Estudante F: Eu tenho uma pergunta/ no caso/ essa lei que eles tinham que não precisava ter permissão da pessoa pra//

3. Professora: É que não tinha lei que não podia/ entendeu? Era livre/

4. Estudante $F$ : Tanto pra negro quanto pra branco essa lei?

5. Professora: Sim/ exatamente/ Só que/ infelizmente/ o que acabava acontecendo?

6. Estudante F: Era mais pra negro/

7. Professora: Era mais pra negros e pessoas mais humildes/Infelizmente/ Mas/ não tinha uma lei que dizia assim/ não pode/ Hoje em dia tem que ter o consentimento para coisas desse tipo/

Inicialmente, a professora abordou o uso do corpo pela ciência e a segregação praticada pelo hospital que atendeu Henrietta. Em seguida, o estudante $\mathrm{F}$ questionou se o processo alterizador (uso científico não consentido de tecidos do corpo) era válido igualmente para brancos e negros. Seguiram-se turnos de fala bastante representativos: "4. Estudante F: Tanto pra negro quanto pra branco essa lei?; 5. Professora: Sim/ exatamente/ Só que/ infelizmente/ o que acabava acontecendo?; 6. Estudante F: Era mais pra negro/; 7. Professora: Era mais pra negros e pessoas mais humildes".

Esse episódio indica que a abordagem de ensino foi potencial para gerar o tipo de questionamento feito pelo Estudante $\mathrm{F}$, que se relaciona à expectativa de ensino apostada. O turno de fala 5 contém um questionamento para que as/os estudantes percebam que, mesmo que a lei fosse geral, o processo alterizador incidia em pessoas negras. $O$ processo de ensino desenvolvido, baseado em QSC, visou superar a postura passiva e receptora da/o estudante em relação às informações fornecidas pela/o docente por uma relação em que ambos constroem conhecimentos ativamente (CONRADO; NUNES-NETO, 2018). Assim, a professora atuou como uma mediadora crítica, que orienta e facilita a aprendizagem, além de fornecer apoio 
emocional e teórico, por meio de atividades de reflexão sobre as informações (CONRADO; NUNES-NETO, 2018).

Ao discutir sobre movimentos sociais e o movimento negro, a professora objetivou diferenciar raça biológica de raça social, o que segue no seguinte episódio.

Quadro 3. Episódio de ensino 4: “É perigoso você dizer que socialmente não existe raça".

1. Professora: é importante a gente falar sobre a diferença de raça biológica e raça social/ raça biológica não existe/ então geneticamente não existe diferença entre uma pessoa negra e uma pessoa branca/todos somos Homo sapiens/ todos somos da mesma espécie/ então não tem a diferença de raça/ não tem um conjunto de genes que consegue agrupar negros e consegue agrupar/ biologicamente não existe isso/ mas existe a raça social/ que a gente sabe/ por causa que senão não existiria o racismo/ então raça social/ raça cultural existe/ e as próprias ciências sociais que vieram com esse conceito de raça/ elas criaram um conceito e esse conceito por incrível que pareça/ ele é muito importante que ele se mantenha/ Por que isso? Por que é importante manter o conceito de raça das ciências sociais? ((pausa)) $O$ que vocês acham? Por que é importante? ((silêncio)) Porque não existe/ biologicamente/ conceitualmente/ não existe raça/ mas por que que é importante manter raça social?

2. Estudante $A$ : Então/ é perigoso você dizer que socialmente não existe raça porque você nega o prerrogativo [i. e. a prerrogativa] do racismo/ então quando você fala raça não existe então não existe o racismo ((muitxs estudantes concordam positivamente com a cabeça))/ mas acontece que não é um conceito/ não é/ não é unânime entre as pessoas/tem gente que acredita que raça biológica existe/ então por isso que você precisa desse conceito social pra discutir esses fenômenos que acontecem e tentar arrumar uma solução pra isso/ ((inaudível))

3. Professora: Perfeito/ muito bom/ isso mesmo/ então a raça/ é importante que se continue com esse conceito social e cultural como o Estudante A falou/ senão não existe/ se a gente pensar ah todo mundo é igual/ se todo mundo é igual não existe racismo/ mas é igual? Igual vocês falaram sobre o caso do avi ão/ não é igual/ existe preconceito/ existe racismo infelizmente ainda/ então o conceito ele é bastante importante/

Esse episódio de ensino evidencia a relevância de tratar o problema ético do racismo também pela via da discussão conceitual sobre raça. Ainda que não tenha havido um aprofundamento da temática, avaliamos que houve reconhecimento pelas/os estudantes de que o conceito social de 
raça é necessário para o combate ao racismo. A mobilização dessa interpretação de raça como construção social, e não como conceito classificatório de grupos biológicos, tem sido apontada como positiva no tratamento das questões étnico-raciais no ensino de ciências e biologia (VERRANGIA, 2016), concernentes com as ações pretendidas pela lei 10.639/2003. Ademais, está presente nas Diretrizes Curriculares Nacionais para Educação das Relações Étnico-Raciais e para o Ensino da História e Cultura Afro-Brasileira e Africana a compreensão de raça como uma construção social forjada nas tensas relações entre pessoas brancas e negras, muitas vezes simuladas como harmoniosas, nada tendo a ver com o conceito biológico de raça cunhado no século XVIII e hoje sobejamente superado (BRASIL, 2004).

Para finalizar o conjunto de evidências acerca da validade da expectativa de ensino, discutimos o episódio 10 , selecionado da aula 3 , que tratou, por meio de exposição dialogada, principalmente dos temas ética e alterização negativa. Após a explicação sobre a alterização, enquanto fenômeno comum da produção cultural de outros, que pode ser positiva, negativa ou neutra (ARTEAGA et al., 2015), a professora solicitou exemplos de alterização negativa, conforme recorte abaixo.

Quadro 4. Episódio de ensino 10: “Alterização que a gente chama de negativa".

1. Professora: a gente vai focar mais nessa coisa "mais ruim"/ certo? Na alterização que a gente chama de negativa/ e aí/ Quais seriam mais especificamente os exemplos?

2. Estudante A: grupos trans/grupos LGBT de maneira geral

3. Professora: Exato

4. Estudante $A$ : minorias étnicas também

5. Professora: isso/ exatamente/ perfeito// que mais? Teria mais algum?

6. Estudante B: ciganos?

7. Professora: sim/

8. Estudante C: até a xenofobia por exemplo/ o nazismo/ aqui no Brasil/ por exemplo

9. Professora: os judeus né/ foram uma alterização/ na época

10. Estudante $C$ : as religiões de matriz africana

11. Estudante D: a questão da migração/ tipo que tá bem atual/ a xenofobia no caso/ dos mexicanos e tal

12. Professora: então isso que a gente acabou de ver né/ que seria o que a Estudante $A$ falou/ racismo/ sexismo/ LGBTfobia/ opressão por extrato econômico/ e o próprio especismo// 
Esse episódio evidencia o reconhecimento de exemplos de alterizações negativas pelas/os estudantes. Embora o foco da SD tenha sido discutir as alterizações a que Henrietta Lacks esteve submetida, o processo de ensino explicitou que a base moral da problemática da construção de outros subjugados, marginalizados e excluídos, é a mesma. Assim, racismo, sexismo, opressão de classe, LGBTfobia e especismo são formas de alterização negativa que geram diversos níveis de opressão e violência a um ser, a grupos de seres ou a grupos sociais que são dignos de consideração moral.

Utilizamos e validamos essa expectativa de ensino por considerarmos que tanto o estudo da história das justificativas científicas de alterização, marginalização e subjugação de grupos e indivíduos humanos no passado e no presente, quanto o uso de outras aproximações filosóficas ou sociológicas ao problema da alterização, podem ter papel formativo importante (ARTEAGA et al., 2005), de modo que a análise de situações concretas que envolvem processos de alterização no ensino de biologia, como realizada neste estudo, pode ser potencial para situar as/os estudantes de modo mais reflexivo nas relações de poder nas quais suas próprias vidas podem estar inseridas.

\section{Considerações finais}

Os resultados deste estudo apontam a relevância da abordagem de ensino, sendo alguns elementos centrais nessa inferência: a organização de questões orientadoras baseadas numa QSC com caso real, que favoreceu a identificação, análise, discussão e crítica de diferentes situações que envolvem alterizações negativas; o tratamento do problema ético-político do racismo pela via da discussão conceitual sobre raça, por meio da consideração de raça como construção social, e não como conceito classificatório de grupos biológicos; e a postura dialógica e explicitamente política da professora que, em consonância com os pressupostos freireanos, os quais entendem a educação como fenômeno diretivo e político em si, não recusou-se a expressar seus posicionamentos e valores, respeitando as falas das/os estudantes e permitindo-Ihes fazer as suas próprias escolhas.

Concluímos que o uso didático de uma QSC com caso real foi potencial na promoção de articulações entre os domínios CTSA e destes com os pressupostos freireanos, por meio da análise de situações concretas de alterização negativa. Nesse sentido, consideramos que, além das razões teóri- 
cas sobre a relevância da abordagem de ensino baseada na expectativa apostada, o estudo produziu evidências empíricas da relevância do ensino que propicia a análise de situações concretas que envolvem alterizações negativas. Assim, julgamos que a abordagem apresenta o potencial de ser utilizada por outras/os docentes em contextos de ensino semelhantes ao nosso, bem como, por meio de adaptações, a contextos de ensino distintos.

\section{Referências}

ADAMS, Carol J. A política sexual da carne: a relação entre o carnivorismo e a dominância masculina. São Paulo: Alaúde Editorial, 2012.

AMARAL, Edênia Maria Ribeiro do; MORTIMER, Eduardo Fleury. Uma metodologia para análise de dinâmica entre zonas de um perfil conceitual no discurso da sala de aula. In: SANTOS, Flavia Maria Teixeira dos; GRECA, Ileana Maria. A pesquisa em Ensino de Ciências no Brasil e suas Metodologias. ljuí: Ed. Unijuí, 2006, p. 239-296.

ARTEAGA, Juanma et al. Alterização, biologia humana e biomedicina. Scientiae Studia, v. 13, n. 3, p. 615-641, 2015.

BRASIL. Conselho Nacional de Educação. Ministério da Educação. Diretrizes Curriculares Nacionais para a Educação das Relações Étnico-Raciais e para o Ensino de História e Cultura Afro-Brasileira e Africana. Brasília, 2004.

CARVALHO, Ítalo Nascimento; NUNES-NETO, Nei Freitas; EL-HANI, Charbel Niño. Como selecionar conteúdos de biologia para o ensino médio? Revista de Educação, Ciências e Matemática. Duque de Caxias, v. 1, n. 1, p. 67-100, 2011.

COBERN, William W.; LOVING, Cathleen C. Defining "science" in a multicultural world: implications for science education. Science Education, New York, v. 85, n. 1, p. 50-67, 2001. 
CONRADO, Dália Melissa; NUNES-NETO, Nei. Questões Sociocientíficas e dimensões conceituais, procedimentais e atitudinais dos conteúdos no ensino de ciências. In: CONRADO, Dália Melissa; NUNES-NETO, Nei. (Org.) Questões Sociocientíficas: fundamentos, propostas de ensino e perspectivas para ações sociopolíticas. Salvador: EDUFBA, 2018. p. 77-118.

CONRADO, Dália Melissa; CONRADO, Iris Selene. Análise crítica do discurso sobre imagens da ciência e da tecnologia em argumentos de estudantes de biologia. Revista Pesquisa Qualitativa. São Paulo, v. 4, n. 5, p. 218-231, 2016.

DAVIS, Angela. Mulheres, raça e classe. Tradução Heci Regina Candiani. São Paulo: Boitempo, 2016.

FANON, Frantz. Os condenados da terra. Rio de Janeiro: Civilização Brasileira, 1968.

FREIRE, Paulo. Pedagogia do oprimido. 64. ed. Rio de Janeiro/São Paulo: Paz e Terra, 2017.

GAMBLE, Vanessa Northington. Under the shadow of Tuskegee: African Americans and health care. American journal of public health, v. 87, n. 11, p. 1773-1778, 1997.

GIL, Antonio Carlos. Estudo de caso. São Paulo: Atlas, 2009.

HODSON, Derek. Realçando o papel da ética e da política na educação científica: algumas considerações teóricas e práticas sobre Questões Sociocientíficas. In: CONRADO, Dália Melissa; NUNES-NETO, Nei. (Org.) Questões Sociocientíficas: fundamentos, propostas de ensino e perspectivas para ações sociopolíticas. Salvador: EDUFBA, 2018, p. 27-57.

LIMA, Gleisa Pereira de Souza; TEIXEIRA, Paulo Marcelo Marini. Análise de uma sequência didática de Citologia baseada no Movimento CTS. In: ENCONTRO NACIONAL DE PESQUISA EM EDUCAÇÃO EM CIÊNCIAS, 2011, 8., Campinas. Atas... Campinas: Associação Brasileira de Pesquisa em Educação em Ciências, 2011. 
MELO, Iran Ferreira de. Análise do discurso e análise crítica do discurso: desdobramentos e interseç̧ões. Letra Magna - Revista Eletrônica de Divulgação Científica em Língua Portuguesa, Linguística e Literatura, São Paulo, v. 5, n. 11, p. 1-18, 2009.

PAIVA, Ayane de Souza. Conhecimentos tradicionais e ensino de biologia: desenvolvimento colaborativo de uma sequência didática sobre reprodução vegetal. 225 f. 2014. Dissertação (Mestrado em Educação) UFBA, Salvador, 2014.

PAIVA, Ayane de Souza. Princípios de design para o ensino de biologia celular: pensamento crítico e ação sociopolítica inspirados no caso de Henrietta Lacks. 391 f. 2019. Tese (Doutorado em Ensino, Filosofia e História das Ciências). UFBA, Salvador, 2019.

PAIVA, Ayane de Souza et al. Design principles for a didactic sequence on cell biology contextualized by social and ethical issues. Conexão Ciência, v. 12, n. esp. 2, p. 76-82, 2017.

PAIVA, Ayane de Souza et al. Baartman, Lacks e o corpo da mulher negra como paradigma de alteridade na história da biologia. In: 15o Seminário Nacional de História da Ciência e Tecnologia (15o SNHCT). Florianópolis, Anais..., Florianópolis, SBHC, 2016.

PAIVA, Ayane de Souza; GUIMARÃES, Ana Paula Miranda; ALMEIDA, Rosiléia Oliveira de. Biologia celular: uma revisão sistemática sobre experiências didáticas no ensino médio. ALEXANDRIA Revista de Educação em Ciência e Tecnologia, Florianópolis, v. 11, n. 2, p. 201-229, 2018.

PEDRETTI, Erminia G.; NAZIR, Joanne. Currents in STSE Education: Mapping a Complex Field, 40 Years On Currents in STSE Education: Mapping a Complex Field, 40 Years On. Science Education, v. 95, n. 4, p. 601-626, 2011.

PÉREZ, Leonardo Fabio Martínez; LOZANO, Diana Lineth Parga. La emergencia de las cuestiones sociocientíficas en el enfoque CTSA. Góndola enseñ. aprendiz. cienc. v. 8, n. 1, p 23- 35, 2013. 
PLOMP, Tjeerd. Educational design research: An introduction. In: PLOMP, Tjeerd; NIEVEEN, Nienke. (Eds.). An introduction to educational design research. Enschede: SLO - Netherlands Institute for Curriculum Development, 2009. p. 9-35.

SANTOS, Wildson Luiz Pereira dos. Scientific literacy: a freirean perspective as a radical view of humanistic. Science Education, v. 93, p. 361-382, 2008.

SINGER, Peter. Libertação animal. Porto Alegre: Lugano, 2004.

SINGER, Peter. Ética prática. Trad. de Jefferson Luiz Camargo. 3. ed. São Paulo: M. Fontes, 2012. 399 p.

SKLOOT, Rebecca. A vida imortal de Henrietta Lacks. Trad. Ivo Korytowksi. São Paulo: Companhia de Letras, 2011.

TORRES, Carlos Alberto. Novos pontos de partida da pedagogia política de Paulo Freire. In: Torres, Carlos Alberto et al. (Org.) Reinventando Paulo Freire no século 21. São Paulo: Editora e Livraria Instituto Paulo Freire, 2008. p. 41-55.

TRIVIÑOS, Augusto Nibaldo Silva. Introdução à pesquisa em ciências sociais: a pesquisa qualitativa em educação. São Paulo: Atlas, 2012.

VAN DEN AKKER, Jan. Principles and Methods of Development Research. In: VAN DEN AKKER, Jan et al. (Ed.), Design approaches and tools in education and training. Boston: Kluwer Academic, 1999. p. 1-14.

VERRANGIA, Douglas. Criações docentes e o papel do ensino de ciências no combate ao racismo e a discriminações. Educação em Foco, v. 21, n. 1, p. 79-103, 2016.

ZEIDLER, Dana L. et al. Beyond STS: a research-based framework for socioscientific issues education. Science Education, v. 89, p. 357-377, 2005. 